\title{
BIOCONVERSION OF WASTE BREAD TO GLUCOSE FRUCTOSE SYRUP AS A VALUE-ADDED PRODUCT
}

\author{
Julija Riaukaite*, Loreta Basinskiene, Michail Syrpas \\ Department of Food Science and Technology, Faculty of Chemical Technology, Kaunas University of Technology, Radvilenu pl. 19, \\ Kaunas, Lithuania, e-mail: julija.riaukaite@ktu.edu
}

\begin{abstract}
Bread is one of the most wasted products of all food in many countries around the world. Bread waste is a resource of carbohydrates, proteins and lipids which can be reused in order to get value-added products. In this study, bread residues were converted into a glucose syrup via two stage enzymatic hydrolysis. The optimization process and response surface methodology were used to find the optimal

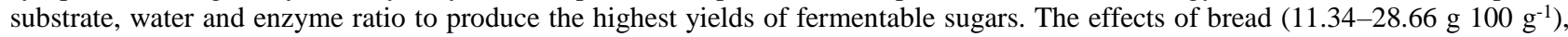
$\alpha$-amylase (0.013-0.047 KNU g ${ }^{-1}$ bread) and glucoamylase $\left(0.23-0.57 \mathrm{AGU} \mathrm{g}^{-1}\right.$ bread) loadings were investigated at liquefaction and saccharification stages. Results indicated that the amount of both enzymes was significant and determines the final glucose yield. Isomerization was performed for glucose conversion to fructose using optimal amounts of materials determined in hydrolysis experiments. Another optimization process was performed to determine the most effective amount of glucose isomerase enzyme (2.59-5.41 IGIU g ${ }^{-1}$ syrup) and $\mathrm{pH}$ (6.79-8.21). The increase in enzyme loading and $\mathrm{pH}$ up to 8 accelerated isomerization reaction. With the optimal process parameters, the highest fructose yield was achieved (40.32\%). Hydrolysis and isomerization processes show bread waste potential of being a resource for the bioproduction of higher value products.
\end{abstract}

Keywords: bread waste, bioconversion, enzymatic hydrolysis, isomerization

\section{Introduction}

Bread is one of the main carbohydrate sources in human diet. Because of today's new technologies and attempt to satisfy consumers' needs, large quantities of bakery products are produced every day. Bread has a relatively short shelf life and about one-third of all that is produced goes to waste. It was estimated that approximately 1.2 million tonnes of bread are thrown away annually (Melikoglu, Webb, 2013).

Bread residues mostly consist of polysaccharides and small amounts of disaccharides. It is a potential biosource for production of fermentable sugars. Compared with traditional waste treatment methods, such as composting, incineration, landfill or other waste disposals, bioconversion to sugars is an environmentally friendly technology (Haroon et al., 2016; Hudeckova et al., 2017). Starch can be converted into glucose by using enzymatic hydrolysis. This process contains two stages. Firstly, enzyme $\alpha$-amylase is used to liquefy bread slurry and obtain dextrins as well as small amounts of glucose. In the second stage, enzyme glucoamylase breaks down dextrins into glucose molecules (Demirci et al., 2017; Mojovic et al., 2006). To produce fructose syrup, hydrolyzed bread is further processed by the addition of enzyme glucose isomerase, which converts glucose into its isomer - fructose. This reaction is equilibrium limited therefore the final product is glucose-fructose syrup (Gaily et al., 2010; Gaily et al., 2012).

Sugar hydrolysates, obtained from conversion of glucose, can be used for various purposes: as sucrose substitute for production of bread and bakery products, as sweeteners or bulking agents in confectionery as well as further processed into high fructose syrup (HFS). HFS can be further converted to hydroxymethylfurfural and used for biofuel production (Dehkordi et al. 2009; Kwan et al., 2018).

The aim of this research is to create a multi-enzymatic composition and optimize the operating conditions of waste bread bioconversion to glucose-fructose syrup that ensures economical production and high yields of the final product.

\section{Materials and Methods \\ Raw materials}

Three loaves of wheat-rye bread were obtained from a local supermarket in Kaunas, Lithuania. Wheat-rye bread was prepared with sourdough. The ingredients used in preparation were rye and wheat flour, water, sugar, salt, yeast and caraway. After shelf life, bread slices were dried in ambient conditions, powdered by a laboratory mill, an average sample was made for analysis and stored at $-20{ }^{\circ} \mathrm{C}$ until use. The moisture of bread $(8.77 \pm 0.04 \%)$ was determined by the standard drying method in an oven at $105^{\circ} \mathrm{C}$ to constant mass. Starch content was measured spectrophotometrically using commercial Megazyme test kit based on AACC International Approved Method 76-13.01 and it was $85.58 \pm 0.69 \%$ of bread dry matter.

Enzymes

A thermostable $\alpha$-amylase (Liquoflow ${ }^{\circledR}$ ) is produced by a genetically modified strain of Bacillus. The enzyme activity is $240 \mathrm{KNU} \mathrm{g}^{-1}$ bread (the amount of $\alpha$-amylase which breaks down $5.26 \mathrm{~g}$ of starch per hour).

Glucoamylase (Saczyme® Plus $2 \mathrm{X}$ ) is produced by selected strains of Aspergillus niger. The enzyme activity is $1500 \mathrm{AGU} \mathrm{g}^{-1}$ bread (the amount of enzyme which hydrolysis $1 \mu \mathrm{mol}$ maltose per minute).

Glucose isomerase (Sweetzyme ${ }^{\circledR}$ IT) is an immobilized enzyme, produced from a selected strain of Streptomyces murinus. A typical activity is 400 IGIU g $^{-1}$ bread (the amount of enzyme which converts glucose to fructose at an initial rate of

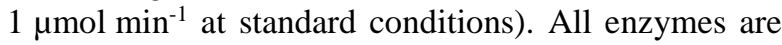
produced by Novozyme JSC, Denmark. 


\section{Bread waste hydrolysis and isomerisation}

The optimization process of bread waste hydrolysis was investigated by using response surface methodology (RSM) and central composite design (CCD). DesignExpert 7.0.0 software (Stat-Ease Inc., Minneapolis, USA) was used for studying the effect of three independent variables (bread, $\alpha$-amylase and glucoamylase loadings). Complete experiment consisted of 18 runs and all runs were performed in duplicate. Results were analysed and a mathematical model that fitted the best by one-way analysis of the variance (ANOVA) was selected.

Bread waste hydrolysis was conducted according to modified Demirci et al. (2017) method. The enzymatic reaction was performed in $250 \mathrm{~mL}$ conical flasks. Various weight ratios of powdered bread

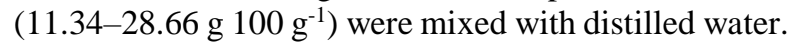
$\mathrm{pH}$ was adjusted to 5.6 using $1 \mathrm{~mol} \mathrm{~L}^{-1}$ concentration $\mathrm{NaOH}$ solution. Conical flasks were covered with aluminium foil and placed in a $45{ }^{\circ} \mathrm{C}$ water bath for $20 \mathrm{~min}$ with $2.5 \mathrm{~Hz}$ stirring speed. The temperature was raised to $60{ }^{\circ} \mathrm{C}$, various concentrations of thermostable $\alpha$-amylase $\left(0.013-0.047 \mathrm{KNU} \mathrm{g}^{-1}\right.$ bread) were added and the total sample weight was adjusted to $100 \mathrm{~g}$ by the addition of distilled water. Samples were further heated to $90{ }^{\circ} \mathrm{C}$ for $60 \mathrm{~min}$ in the drying oven and cooled to $50{ }^{\circ} \mathrm{C}$.

In the saccharification stage $\mathrm{pH}$ of the samples was adjusted to 4.3 with $1 \mathrm{~mol} \mathrm{~L}^{-1}$ concentration $\mathrm{H}_{2} \mathrm{SO}_{4}$ solution and various amount of glucoamylase (0.23-0.57 AGU g ${ }^{-1}$ bread) were added to the mixture. Flasks were placed in a $65^{\circ} \mathrm{C}$ water bath for 24 hours with $2.5 \mathrm{~Hz}$ stirring speed. Samples were withdrawn during the experiment and stored at $-20^{\circ} \mathrm{C}$ until analysis.

One solution for obtaining a high yield of glucose was selected based on Design-Expert software. Bread loading (18.64 g $\left.100 \mathrm{~g}^{-1}\right)$, the amount of $\alpha$-amylase (0.03 KNU g ${ }^{-1}$ bread) and glucoamylase (0.43 AGU g-1 bread) were chosen for process optimization. The amount of glucoamylase and $\mathrm{pH}$ were optimized using RSM and CCD. The experiment had 12 runs in total and all runs were performed in duplicate. Results were analysed using methodology described previously.

Glucose conversion to fructose was conducted according to modified Gaily et al. (2010) method. Bread slurry was filtered using a sieve and $100 \mathrm{~mL}$ of filtrate was poured into $250 \mathrm{~mL}$ conical flasks. $\mathrm{pH}$ was adjusted to 6.79-8.21 and various amounts of glucose isomerase enzyme (2.59-5.41 IGIU $\mathrm{g}^{-1}$ syrup) were added (Table 2). Flasks were covered with aluminium foil and placed into a $65^{\circ} \mathrm{C}$ water bath with $2 \mathrm{~Hz}$ stirring speed.

\section{Determination of glucose and fructose}

Glucose and fructose content in the samples was determined by enzymatic K-FRUGL 05/17 test (Megazyme International Ireland Limited, Ireland). The concentrations of D-glucose and D-fructose were measured spectrophotometrically using commercial test kit. D-glucose and D-fructose yields were calculated according to equations in the Megazyme assay procedure.

\section{Statistical Analysis}

Mean values and standard deviations were calculated using MS Excel. IBM SPSS Statistics 23 (SPSS, Inc., Chicago, IL) was used for statistical data analysis. Oneway analysis of variance (ANOVA) with Tukey's posthoc test was performed and significant differences were determined at $\alpha=0.05$.

\section{Results and Discussion}

Glucose yield was investigated to optimize waste bread hydrolysis. Although the optimal amount of enzymes is recommended by the producer, the interval of the values is quite wide and adapted to the hydrolysis of starch rather than bread. Bread loading should be optimal because small amount of bread will result in low glucose yield and too high concentration of bread will give a very thick slurry, what makes harder for enzymes to break down all starch (Ebrahimi et al., 2008; Zhang et al., 2004).

Table 1

Optimization of bread waste hydrolysis

\begin{tabular}{|c|c|c|c|c|c|}
\hline \multirow[b]{2}{*}{ No } & \multicolumn{3}{|c|}{ Hydrolysis parameters } & \multicolumn{2}{|c|}{ Glucose yield, \% } \\
\hline & 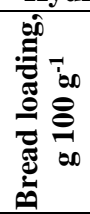 & 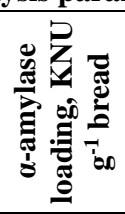 & 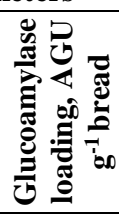 & 矛 & D. \\
\hline 1 & 15.00 & 0.020 & 0.30 & $66.52 \pm 1.22^{\mathrm{a}}$ & 66.29 \\
\hline 2 & 25.00 & 0.020 & 0.30 & $57.08 \pm 1.03^{b c}$ & 56.84 \\
\hline 3 & 15.00 & 0.040 & 0.30 & $77.82 \pm 1.77^{h}$ & 77.58 \\
\hline 4 & 25.00 & 0.040 & 0.30 & $64.60 \pm 1.92^{\mathrm{fg}}$ & 64.37 \\
\hline 5 & 15.00 & 0.020 & 0.50 & $73.49 \pm 0.44^{\mathrm{bc}}$ & 73.25 \\
\hline 6 & 25.00 & 0.020 & 0.50 & $66.00 \pm 2.40^{\mathrm{b}}$ & 65.77 \\
\hline 7 & 15.00 & 0.040 & 0.50 & $80.19 \pm 0.61^{b c}$ & 79.96 \\
\hline 8 & 25.00 & 0.040 & 0.50 & $71.01 \pm 1.92^{\mathrm{fg}}$ & 70.77 \\
\hline 9 & 11.34 & 0.030 & 0.40 & $68.99 \pm 1.52^{\mathrm{a}}$ & 69.31 \\
\hline 10 & 28.66 & 0.030 & 0.40 & $65.39 \pm 1.09^{\mathrm{gh}}$ & 65.70 \\
\hline 11 & 20.00 & 0.013 & 0.40 & $62.57 \pm 0.86^{b c}$ & 62.89 \\
\hline 12 & 20.00 & 0.047 & 0.40 & $83.38 \pm 0.14^{\mathrm{gh}}$ & 83.70 \\
\hline 13 & 20.00 & 0.030 & 0.23 & $56.40 \pm 1.58^{\mathrm{de}}$ & 56.72 \\
\hline 14 & 20.00 & 0.030 & 0.57 & $77.50 \pm 2.86^{\mathrm{h}}$ & 77.81 \\
\hline 15 & 20.00 & 0.030 & 0.40 & $83.53 \pm 2.58^{\mathrm{ef}}$ & 83.45 \\
\hline 16 & 20.00 & 0.030 & 0.40 & $84.82 \pm 1.87^{\mathrm{h}}$ & 83.45 \\
\hline 17 & 20.00 & 0.030 & 0.40 & $83.96 \pm 0.43^{\mathrm{h}}$ & 83.45 \\
\hline 18 & 20.00 & 0.030 & 0.40 & $81.52 \pm 0.29^{\mathrm{cd}}$ & 83.45 \\
\hline
\end{tabular}

Different superscript letters within a column indicate significant differences (one-way ANOVA and Tukey's test, $\mathrm{p}<0.05$ ).

Process parameters, experimental and predicted values of glucose yields are presented in Table 1. Analysis of response surface showed that the model itself was significant according to the Student test $(p=0.0005)$ and the "lack of fit" was not significant $(p=0.5191)$. The significant independent variables in the model $(\mathrm{p}<0.05)$ were $\alpha$-amylase and glucoamylase loadings. Obtained results revealed that glucoamylase loading with the 
$F$ value $=128.86$ had a slightly larger effect on the total glucose yield than $\alpha$-amylase $(\mathrm{F}=125.38)$. The determination coefficient $\left(\mathrm{R}^{2}=0.9955\right)$, which indicates the ability of the model to predict results, confirmed the adequacy of the model. An adequate ratio, which measures the signal to noise ratio, was 23.28. A ratio greater than 4 is desirable and indicates an adequate signal. More than 5 times higher value proved that this model can be used to navigate the design space.

3D and 2D response surface plots illustrate the effect of hydrolysis parameters on the total glucose yield (Figure 1). Plots were created considering one of the independent variables as a constant meanwhile the other two were changing and predicting response. Picture $1 \mathrm{~A}$ shows the effect of bread versus $\alpha$-amylase loading at a constant glucoamylase loading (0.40 $\mathrm{AGU} \mathrm{g}^{-1}$ bread). Results indicate that the amount of both bread and $\alpha$-amylase determines the final glucose yield. The highest glucose yield was obtained when bread loading

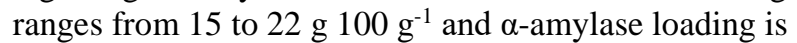
at least $0.032 \mathrm{KNU} \mathrm{g}^{-1}$ bread. Bread loading greater than

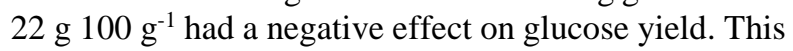
effect can be explained by the formation of a thicker bread slurry before hydrolysis, which is less accessible to enzymes. To obtain the highest glucose yield, the lowest amount of enzyme $\alpha$-amylase is used when bread

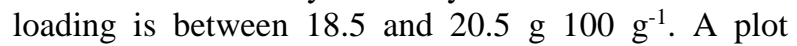
(Fig. 1B) illustrates the effect on bread and glucoamylase loadings at a constant $\alpha$-amylase value of $0.03 \mathrm{KNU} \mathrm{g}^{-1}$ bread. Results show that both independent variables were relevant to the final glucose concentration. The highest yield of glucose was obtained when glucoamylase loading was greater than $0.38 \mathrm{AGU} \mathrm{g}^{-1}$ bread and bread loading ranged from 16.5

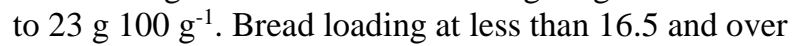

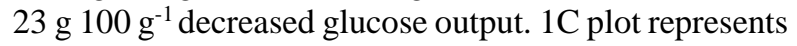
the effect on $\alpha$-amylase and glucoamylase loadings at a

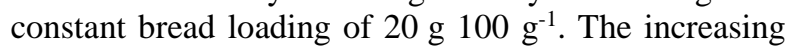
concentrations of enzymes increase glucose yield. The highest yield of glucose was obtained when $\alpha$-amylase loading was greater than $0.027 \mathrm{KNU} \mathrm{g}^{-1}$ bread and glucoamylase loading - more than $0.36 \mathrm{AGU} \mathrm{g}^{-1}$ bread. The final glucose yield ranged from 56.40 to $84.82 \%$. Compared with Demirci et al., 2017 research where glucose yield was $62-86 \%$ obtained yields during the experiment were slightly lower. The difference between results may be due to different type of bread and lower enzymes loadings.

After all results were analysed, a tendency was observed that increasing the amount of enzyme ( $\alpha$-amylase up to $0.047 \mathrm{KNU} \mathrm{g}^{-1}$ bread and glucoamylase to $0.55 \mathrm{AGU} \mathrm{g}^{-1}$ bread) increases glucose yield. Higher loadings of $\alpha$-amylase and glucoamylase did not have a significant effect on a total glucose yield. It was also

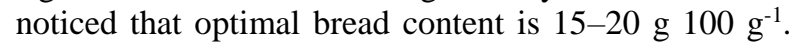
The optimal hydrolysis conditions were determined based on the obtained mathematical model: bread

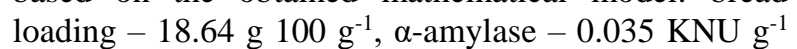
bread and glucoamylase $-0.43 \mathrm{AGU} \mathrm{g}^{-1}$ bread. Under these conditions, $86.10 \%$ yield of glucose was predicted by the software. When the experiment was repeated with suggested values, the total glucose yield of $84.95 \pm 0.47 \%$ was obtained. Similar actual and predicted values confirm that this model is sufficiently accurate and can be adapted for the optimization of hydrolysis process.
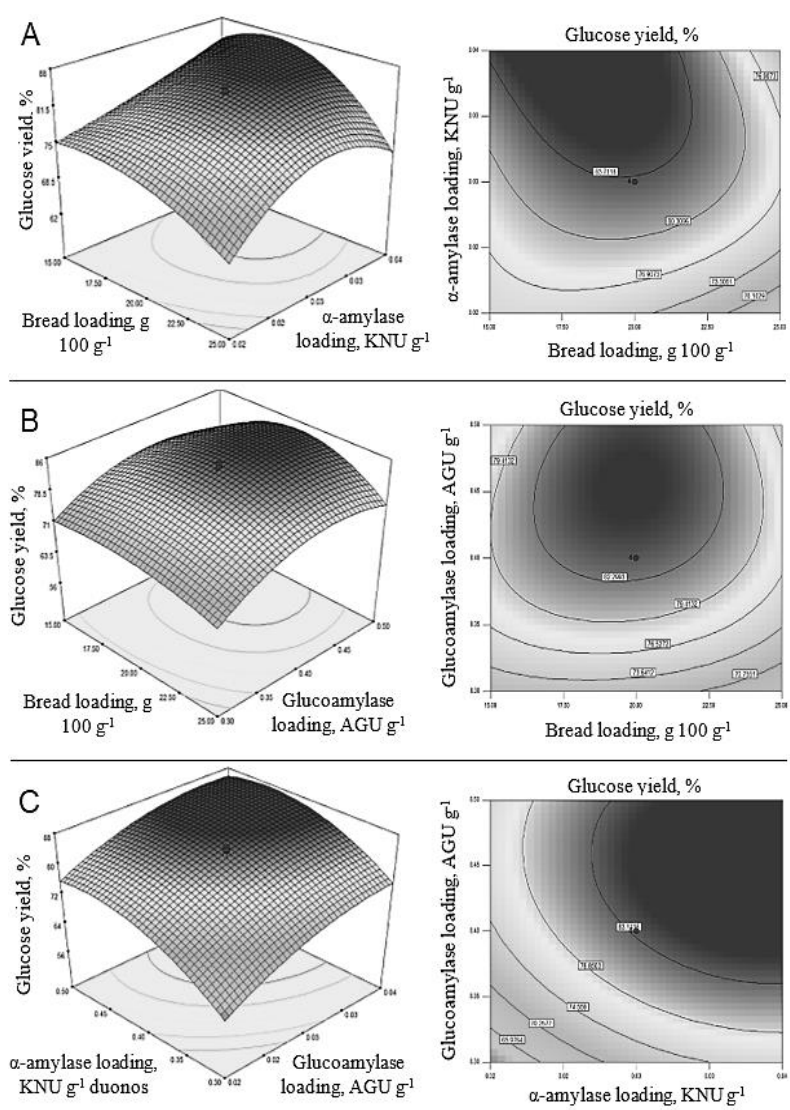

Figure 1. Response surface of the total glucose yield

In order to produce glucose-fructose syrup, the glucose syrup is further processed by adding another enzyme glucose isomerase. This conversion effectiveness mainly depends on the glucose isomerase loading and $\mathrm{pH}$. Isomerization parameters were optimized and the total yield of fructose was selected as the response factor. Process parameters, experimental and predicted values of fructose yields are presented in Table 2 .

Results showed that fructose yield ranges from 32.68 to $40.32 \%$. Compared with data presented in Gaily et al. (2010) research the highest obtained fructose yield was almost the same as the fructose yield (40.9\%) produced in similar conditions. Fructose reached the highest yield at $\mathrm{pH} 7.5$ and at the maximum enzyme loading of 5.41 IGIU g $^{-1}$ of syrup. A high fructose yield $(39.86 \%)$ was also obtained using a slightly lower enzyme loading (5.0 IGIU g ${ }^{-1}$ syrup) but at a higher $\mathrm{pH}(\mathrm{pH} 8)$. However, the results showed that by further increasing the $\mathrm{pH}$, the fructose yield starts to decrease.

ANOVA was used to identify adequacy of the quadratic regression model. The evaluated "lack of fit" coefficient was insignificant with a $p=0.6375$. Student test showed that the model itself was significant $(\mathrm{p}<0.0001$, $\mathrm{F}=131.84)$. The determination coefficient $\left(\mathrm{R}^{2}=0.9910\right)$ 
confirmed the adequacy of the completed model. An adequate ratio was 32.71 which proved that this model can be used to navigate the design space. Both independent variables are significant and have the effect on fructose yield in glucose conversion process. Considering these independent variables, glucose isomerase loading had a greater effect on fructose yield than $\mathrm{pH}$. Their $\mathrm{F}$ values are respectively 288.03 and 227.60 .

Table 2

Optimization of glucose isomerization

\begin{tabular}{ccccc}
\hline & \multicolumn{2}{c}{ Parameters } & \multicolumn{2}{c}{ Fructose yield, \% } \\
\cline { 2 - 5 } No & $\begin{array}{c}\text { Glucose } \\
\text { isomerase } \\
\text { loading, } \\
\text { IGIU g- } \\
\text { syrup }\end{array}$ & pH & Experimental & Predicted \\
\hline 1 & 3.00 & 7.00 & $32.68 \pm 0.27^{\text {de }}$ & 32.40 \\
2 & 5.00 & 7.00 & $37.02 \pm 0.89^{\text {cd }}$ & 36.92 \\
3 & 3.00 & 8.00 & $36.45 \pm 0.71^{\text {f }}$ & 36.47 \\
4 & 5.00 & 8.00 & $39.86 \pm 0.44^{\text {de }}$ & 40.07 \\
5 & 2.59 & 7.50 & $34.31 \pm 0.18^{\mathrm{c}}$ & 34.48 \\
6 & 5.41 & 7.50 & $40.32 \pm 0.80^{\mathrm{a}}$ & 40.23 \\
7 & 4.00 & 6.79 & $32.77 \pm 1.07^{\mathrm{de}}$ & 33.02 \\
8 & 4.00 & 8.21 & $38.31 \pm 0.10^{\mathrm{c}}$ & 38.13 \\
9 & 4.00 & 7.50 & $38.73 \pm 0.71^{\text {ef }}$ & 38.68 \\
10 & 4.00 & 7.50 & $39.02 \pm 0.27^{\mathrm{a}}$ & 38.68 \\
11 & 4.00 & 7.50 & $38.82 \pm 0.18^{\mathrm{b}}$ & 38.68 \\
12 & 4.00 & 7.50 & $38.15 \pm 0.11^{\mathrm{b}}$ & 38.68 \\
\hline
\end{tabular}

Different superscript letters within a column indicate significant differences (one-way ANOVA and Tukey's test, $\mathrm{p}<0.05$ ).

3D and 2D response surface plots show the relationship between independent variables (glucose isomerase loading and $\mathrm{pH}$ ) and response (fructose yield) (Figure 2).
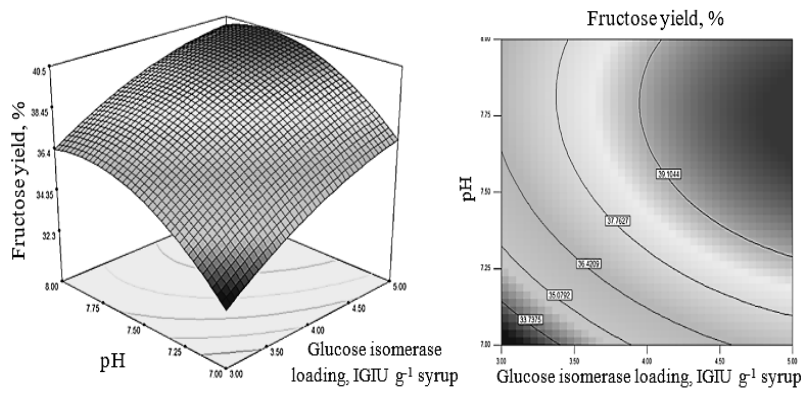

Figure 2. Response surface of the total fructose yield

The results presented in the response surface plots confirmed that the enzyme content and $\mathrm{pH}$ are significant parameters. The highest fructose yield is obtained when enzyme loading is greater than 4.0 IGIU $\mathrm{g}^{-1}$ syrup and $\mathrm{pH}$ is more than 7.3. Considering suggested solutions from Design-Expert 7.0.0 software for fructose yield optimization, the optimal conditions were the following: glucose isomerase loading from 4.84 to 5.0 IGIU $\mathrm{g}^{-1}$ syrup, $\mathrm{pH}$ - from 7.69 to 7.87 . Within these optimization parameter values, the theoretical fructose yields should reach $40.32-40.42 \%$. Isomerization is considered effective because glucose conversion to fructose is equilibrium limited to $42 \%$ fructose (Gaily et al., 2010; Zhang et al., 2004).

\section{Conclusions}

Bread waste hydrolysis and isomerization showed that biotechnological methods can be used for glucosefructose syrup production. The final technological scheme for optimized bioconversion of waste bread consisted of the following steps:

I) preparation of aqueous suspension of bread

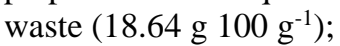

II) liquefaction ( $\alpha$-amylase loading $0.035 \mathrm{KNU} \mathrm{g}^{-1}$ bread);

III) saccharification (glucoamylase loading $0.43 \mathrm{AGU} \mathrm{g}^{-1}$ bread);

IV) isomerization (glucose isomerase loading 4.84-5.0 IGIU g ${ }^{-1}$ syrup, $\mathrm{pH}$ 7.69-7.87).

Using this scheme, it is possible to produce glucosefructose syrup of $45.27 \pm 0.55 \%$ glucose and $40.32 \pm 0.80 \%$ fructose.

\section{Acknowledgment}

The authors acknowledge Novozymes JSC (Denmark) for providing enzymes required for this research.

\section{References}

1. Dehkordi A.M., Tehrany M.S., Safari I. (2009) Kinetics of glucose isomerization to fructose by immobilized glucose isomerase (Sweetzyme IT), Industrial \& Engineering Chemistry Research, Vol. 48(7), p. 3271-3278.

2. Demirci A.S., Palabiyik I., Gumus T., Ozalp S. (2017) Waste bread as a biomass source: optimization of enzymatic hydrolysis and relation between rheological behavior and glucose yield, Waste and Biomass Valorization, Vol. 8(3), p. 775-782.

3. Ebrahimi F., Khanahmadi M., Roodpeyma S., Taherzadeh M.J. (2008) Ethanol production from bread residues, Biomass and Bioenergy, Vol. 32(4), p. 333-337.

4. Gaily M.H., Elhassan B.M., Abasaeed A.E., Al-Shrhan M. (2010) Isomerization and kinetics of glucose into fructose, International Journal of Engineering \& Technology, Vol. 10(3), p. 1-10.

5. Gaily M.H., Sulieman A.K., Abasaeed A.E. (2013) Kinetics of a three-step isomerization of glucose to fructose using immobilized enzyme, International Journal of Chemical Engineering and Applications, Vol. 4, p. 31-34.

6. Haroon S., Vinthan A., Negron L., Das S., Berenjia A. (2016) Biotechnological approaches for production of high value compounds from bread waste, American Journal of Biochemistry and Biotechnology, Vol. 12(2), p. 102-109.

7. Hudeckova H., Supinova P., Babak L. (2017) Optimization of enzymatic hydrolysis of waste bread before fermentation, Acta Universitatis Agriculturae et Silviculturae Mendelianae Brunensis, Vol. 65(1), p. 35-40.

8. Kawa-Rygielska J., Pietrzak W., Czubaszek A. (2012) Characterization of fermentation of waste wheat-rye bread mashes with the addition of complex enzymatic preparations, Biomass and Bioenergy, Vol. 44, p. 17-22. 
9. Kwan T.H., Ong K.L., Haque M.A., Kwan W.H., Kulkarni S., Lin C.S.K. (2018) Valorisation of food and beverage waste via saccharification for sugars recovery, Bioresource technology, Vol. 255, p. 67-75.

10. Melikoglu M., Webb C. (2013) Use of waste bread to produce fermentation products. In: Food Industry Wastes: assessment and recuperation of commodities. Academic Press, p. 63-76.
11. Mojovic L., Nikolic S., Rakin M., Vukasinovic M. (2006) Production of bioethanol from corn meal hydrolyzates, Fuel, Vol. 85(12-13), p. 1750-1755.

12. Zhang Y., Hidajat K., Ray A.K. (2004) Optimal design and operation of SMB bioreactor: production of high fructose syrup by isomerization of glucose, Biochemical Engineering Journal, Vol. 21(2), p. 111-121. 